\title{
Accessing industrial landscapes: the arctic projects of Elin and Carmen Corneil
}

\author{
P. M. Milojevic \\ School of Architecture and Planning, University of Auckland, New Zealand
}

\begin{abstract}
From the mid 1950s, a conceptually and aesthetically more inclusive and conditional sensibility than that of the First Generation Modernists, regarding industrial architecture, came to the fore in the avant-garde 'brutalist' and 'warehouse' way of thinking. In the mid to late 1960s when British and American manufacturing belt cities and landscapes were the subject of research by Cedric Price, Reyner Banham and others, Elin and Carmen Corneil, practicing and teaching in Toronto, both appreciated the heritage but noted the disastrous urban conditions resulting from the physical separation of places or work from the public realm of those cities. In their 1972 urban regeneration project for the largely abandoned industrial Toronto waterfront they extended the city's block and street structure into the port lands. They approached the repair and enhancement of the volcanically-damaged fishing port of Vestmannaeyjar (Iceland) similarly, though responding to the smaller scale of the site, on a more varied and detailed level. In harbour competitions for Nuuk, Nordkapp, Stockholm, Copenhagen, Trondheim, and Oslo in the 1980s they sought to repair the ruptured urban fabric involving cultural heritage. Since the 1990s their Arctic work has involved the re-presentation of industrial landscapes in what are now generally depopulated and abandoned heavy industrial environments of the nationalized, fishing, mining and steel industries. This paper focuses on the Corneils' projects for the exceptional Arctic port-scapes of Melbu, Narvik and Mo-i-Rana, in which they argue for the retention of the coherence of the industrial landscape and the value of robust and direct interventions to effect physical connections and access, establish visual links revealing site histories and accepting the abrupt and symbiotic adjacencies which are the special character of these urban places.
\end{abstract}

Keywords: maritime industrial heritage, urban design, accessibility, interventions, reinterpretation, adaptation. 


\section{Introduction}

The extraordinary and extensive photographic portfolio of industrial buildings by Bernd and Hilla Becher are mostly presented as typological folios, such as Grain Elevators [1], which is an elegant and intelligent extension of the die Neue Sachlichkeit photographic tradition as presented in the Die Blauen Bücher architectural photographic surveys of the mid 1920s. The Bechers' images draw our attention to both standardization and particularity of the industrial structure, to their unselfconscious composition and presentation. The images also convey the inherently limited lifespan of these specific assemblages being as they are under a continuous threat of obsolescence, matter-of-fact transformation, unceremonious abandonment or demolition to accommodate new equipment, processes and layouts responding to changing economies. In Industrial Landscapes [2] the Bechers present a wider perspective on the social realities and topological juxtapositions in industrial environments. For example in Zeche Consolidation, Gelsenkirchen, Ruhrgebiet, D 1974 (fig. 1) we are shown the spatial, physical and social realities of the abrupt juxtaposition of the places of work/production and the domestic/consumption while pointing out the surprising normalcy of such abrupt adjacencies. Such contextualised view points of manufactured landscapes distinguishes the Bechers' approach from that of first-generation Modernists polemicists such as Gropius, Mendelsohn, Le Corbusier and Müller-Wulckow [3] who appreciated the articulated authenticity of industrial constructions but preferred to imagine this architecture in isolation. To illustrate his text on les cathédrales de béton, 'American' grain elevators in Vers une architecture [4], Le Corbusier used a selectively-masked version of an original image which is in fact John S. Metcalf Co's 1912 élévateur à grain $n^{\circ} 2$, rue de la Commune, Montréal. While Le Corbusier's figure suppresses the fact that the enormous 2.6 million bushel capacity grain elevator was sited directly in front of William Footner's 1844 Marché Bonsecours, arguably Canada's most prominent neoclassical public monument and until then the city's centrepiece on the St Lawrence River frontage [5], the elevator's construction is arguably more remarkable as an urban intervention than as an engineering feat or architectural object (fig. 2).

A conceptually and aesthetically more inclusive sensibility, than that evinced by the first generation Modernists, regarding the role and place of industrial architecture as precedent and artefact came to the fore in avant-garde thinking through the articulation, from the late $1950 \mathrm{~s}$ on, of the 'brutalist' and 'warehouse' positions by the Independent Group and then Team 10. When, in the mid to late 1960s Reyner Banham [6], Cedric Price [7] and others were again drawing attention to the industrial architecture heritage in the manufacturing belt cities of the northeastern and central North America the fourth generation Modernists, Elin and Carmen Corneil, practicing and teaching in Toronto, took student architecture study tours to Cleveland, Buffalo, Detroit, Rochester and Chicago. They were also drawing lessons from the disastrous urban consequences of the abandonment and demolition of industrial landscapes there.

When in the early 1970s, with Jeffrey Stinson, the Corneils were asked to coordinate an urban waterfront regeneration project for the largely abandoned 
industrial port of Toronto, their strategy was to develop a community plan, entitled Harbour Passage [8], for public access to the extraordinary places on the industrial waterfront (fig. 3). Harbourfront, their subsequent proposal for the extrapolation of Toronto's downtown block and street structure into this land reclamation area while negotiating around the existing industrial structures, took a diametrically opposite position to that of La Société du Vieux-Port de Montréal [9] which conceptualised the contemporaneous le fenêtre sur le fleuve waterfront reclamation project beginning with the clearance of élévateur $n^{\circ} 2$ as part of the port's masterplan for the linear Promenade de Vieux-Port.

The Corneils' Vestmannaeyjar Nordic Ideas Competition winning project for volcanically-devastated island of Heimay [10], partially realised in the late

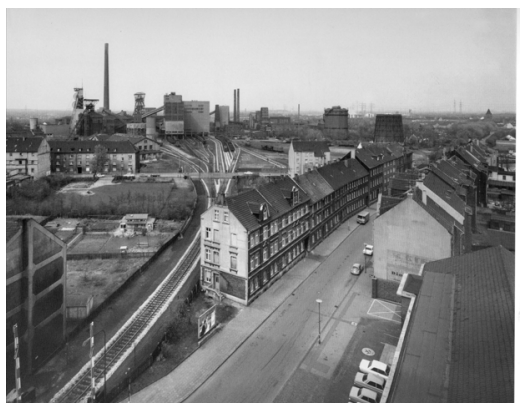

Figure 1: Bernd and Hilla Becher, Zeche Hannover 1/2/5, Bochum-Hordel, Germany, 1987.

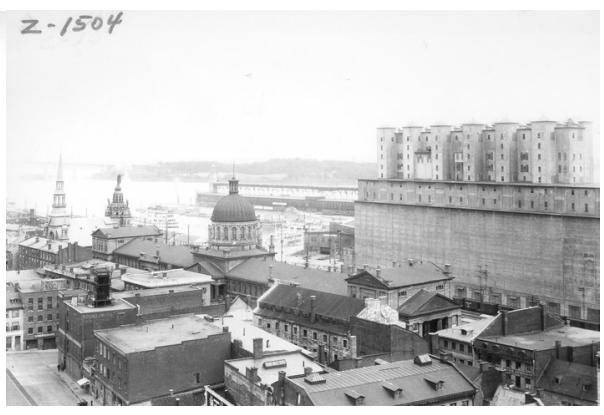

inconnu. Vue aerienne, Le marché Bonsecours et les silos à grain $\quad n^{\circ} 2$, VieuxMontréal. Vers 1933. Courtesy of the Ville de Montréal. Records Management and Archives. Z-1504.

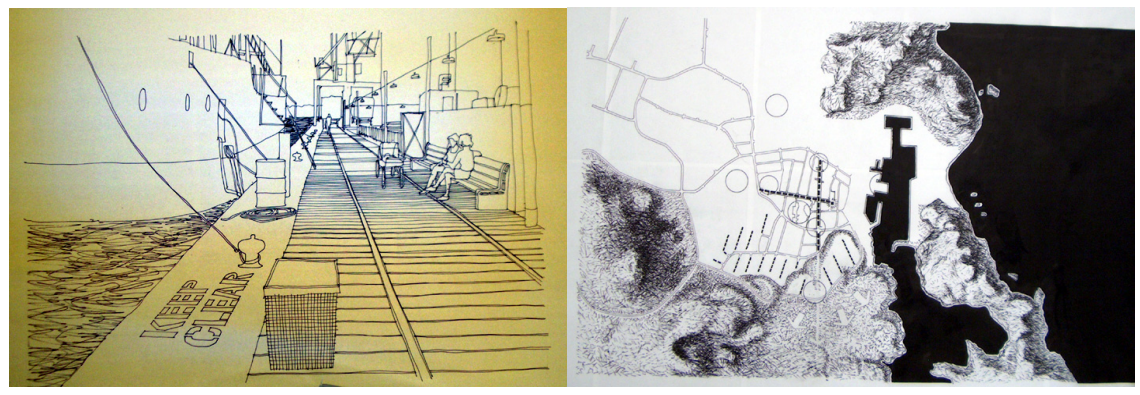

Figure 3: Carmen Corneil. Wharf Figure 4: Elin and Carmen Corneil. Access, Harbour Passage- Relief Site Plan, 72 Toronto. Sketch 1972. Vestmannaeyjar, Iceland, 1976. 
1970s, was based on a close-reading of the varied and detailed existing conditions in this the largest fishing port off the south coast of Iceland (fig. 4).

What set their thinking apart was their insistence on a strategy of repair and infilling of the existing streetscapes, enhancement strategies that is, rather than proposals for a new town centre and housing quarter. In water's edge competition projects for Stockholm, Copenhagen, Trondheim, Rovaniemi and Oslo in the 1980s [10] they also sought to repair, enhance and punctuate urban fabric and industrial heritage at the water's edge; at Nuuk, Tromsø and Nordkapp their projects established historic visual links to the water. When it was feasible in these studies and projects, industrial architecture heritage was included in their identification of elements of the urban fabric as they felt it of paramount importance to highlight the symbiotic relationship between sites of production and those of consumption.

Following their unpremiated competition harbour projects in the 1980s, and practicing now full-time from Trondheim, the Corneils engaged in a series of studies and competition projects for the small Norwegian Arctic ports of Melbu, Narvik, and Mo. This paper focuses on these three projects in which the architects strategized the 're-presentation', for the purposes of cultural tourism, of these largely abandoned and depopulated heavy industrial environments of the nationalized, fishing, mining and steel industries. Reacting to a spate of new Norwegian oil, mining and fishing industry museum projects in Bergen, Kristiansund, $\AA$, Tromsø, and Senjaoya in the 1980s [11] which were all nostalgic, picturesque, symbolic, figurative and representational object buildings (i.e. oil rig'ish or sail boat'y) the Corneil's articulated strategies for cultural projects which propose the engagement of the larger frame of the industrial landscape as well as its particular places and vantage points as a means to a didactic end. Seeking to reveal the spatial, formal and historic coherence of these ports through robust and direct interventions their proposals seek to point out the often abrupt, though symbiotic, sometimes violent and destructive adjacencies in the quasi-urban fabric of the industrial town landscape. By proposing infill, physical connections, public access, and visual links they intend to reveal cultural histories through authentic experiences. They have shown how, by the invention of new places and structures within physically or socially devastated urban areas but still having recognisable cultural value one might move towards the regeneration of whole communities returning the place in some way to that recognisable to those who once knew the site as a viable workplace and social centre. In these projects the architects engage and connect the existing traces of urban structure, including residential fabric, with experiences of normally inaccessible sites of heavy industry while pointing out the grandeur and fragility of the natural setting.

\section{Narvik}

The raison d'être of Narvik's place on a low promontory surrounded by the protected waters of the mountain-ringed Ofotenfjorde is due to it being at the head of a deep water channel open year-round. Developed as a trans-shipment port, the world's busiest above the Arctic Circle, for the Swedish conglomerate 
Luossavaara-Kiirunavaara's AB (LKAB) Kiruna-Malmgebert iron ore mine with Norges Statsbaner (NSB) to manage handling ore in perpetual motion the extensive rail off-loading yards, massive gantry cranes, crushing sheds, conveyors and ore hoists, processing plants and ship-loading wharves (fig.5) occupied a quarter of the central area of the peninsula. Following the reduced demand for iron ore in the world market in the 1960s Narvik's capacity became largely redundant, and much of its industrial zone emptied and static. The depopulated city had by the 1970s refocused on servicing a modest fishing industry and the LKAB and NSB yards and depots became the subject of a 1992 competition which envisioned its recreational and cultural re-use; the enormous crushing shed adjacent to the site, the dominant architectural landmark, was not a part of the project. Of the three sides of the triangular competition site two might be thought of as the front: the fjord side, to which the rail tracks and ore cars were directed (fig. 7), defines the essential land-to-sea condition of the site; the town side (fig. 8) though remained the main approach to the site. The Corneils' winning submission (fig. 6) proposed the enhancing of the pre-existing site conditions and qualities through the accessing of the extraordinary, monumental and forbidding industrial site while developing the potential of Kongensgate as a protected traversable urban thoroughfare by being narrowed, re-curbed and planted. By rerouting the E6 along a defunct parallel rail corridor below Kongensgate and reusing a surplus rail bridge to achieve a level change, they offered vehicular access to a new partially underground parking structure the roof of which is employed as the surface of a small plaza at the KongensgateBrugata intersection at the north-east apex of the site from which they offer pedestrian access to the site by a proposed bridge over the E6 which landing at the town end of the vast LKAB crane yards. On the port side of the site they proposed a blend of existing industrial usages with three new recreational footbridges: at the entrance to the quay from the entrance to town and where the E6 and Kongensgate go their separate ways at the southeast apex of the site, and at either end of a proposed new recreational marina. Complimenting their strategy at the north Kongensgate-town apex of the site they propose access to the centre of the industrial site on elevated viaducts over the heavy vehicle zone of the port (dropping down to grade at the water's edge) and thereby avoiding conflicts of activity. The suburban Frydenlund side of the competition site is bounded by a high embankment cut of the $150 \mathrm{~m}$ wide rail yard terrace. To access the main industrial heritage site, the $700 \mathrm{~m}$ long concrete and steel crane and hoist framework, the Corneils propose two pedestrian tunnels (doubling as thematic exhibition spaces), a viaduct from Kirkegata in the west in addition to the aforementioned ramped gangway from their proposed Brugata-Kongensgate plaza leading to the defunct central control station structure housing a museum of industrial heritage and the adjoining tower becoming a viewing platform on axis with the E6. The Corneils imagine the enormous concrete platforms and crane terrace forecourt to the vast crushing shed to have the potential to be an extraordinary place for a permanent running track inside of which an special events court (on a new $6 \mathrm{~m} \times 7 \mathrm{~m}$ service grid) could be developed for temporary events and installations shared Cedric Price's belief in the value of 
indeterminacy and responsiveness of installations as evinced in Price's 1965 Potteries Thinkbelt and 1976 Interaction where accommodation was setup in a serviced matrix on a marginal rail corridor sidings constructed directly for changing needs.

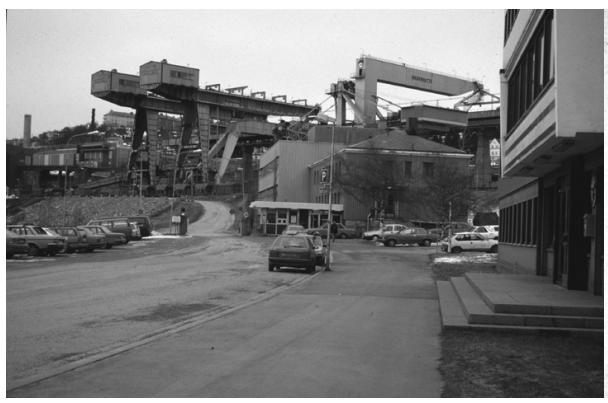

Figure 5: Elin and Carmen Corneil. UNSKAB cranes from the wharf, Narvik, Norway 1992.

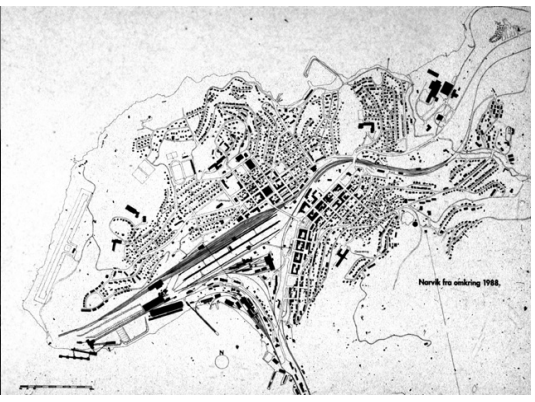

Figure 6: Elin and Carmen Corneil. Site Plan, NAK Konkurranser, Narvik, Norway 1992.

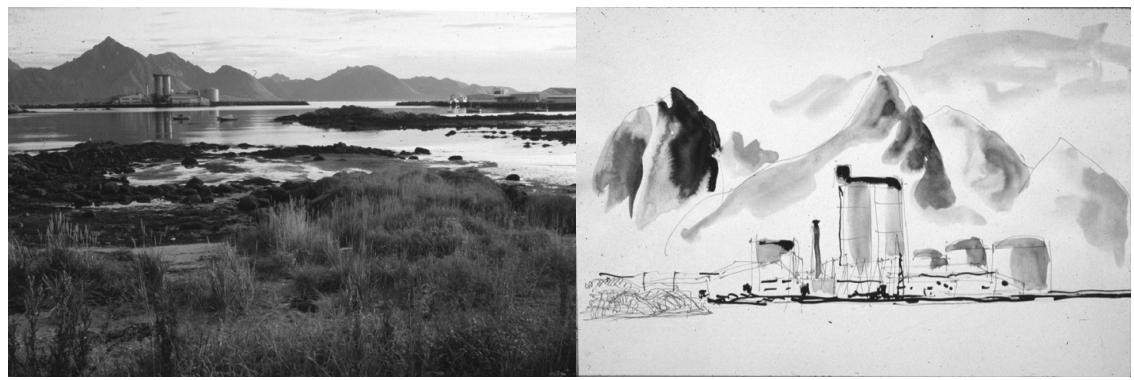

Figure 7: Elin and Carmen Corneil. Figure 8: Carmen Corneil. Neptun Neptun works from Melbu wharf, Norway. Photograph 1990. works from Melbu wharf, Norway. Colour sketch 1990.

\section{Melbu}

While pre-modern herring production involved unloading, open-air filleting and drying on timber racks, and/or steaming, salting, barreling and storage in timber sheds on the Melbu wharves $19^{\text {th }}$ century steam-powered trawlers subsequently brought in greater quantities of the resource to produce meal and oil products. After more than a millennium of export fishing the dramatic near disappearance in the herring and capelin stocks in the 1970s and 1980s precipitated the historic end to oil and fillets processing in this remote location in this mountain-ringed gulf in Austvågøy in the Vesterålen-Lofoten archipelago, (fig. 7) adjacent to some of the world's most significant fishing grounds. Prior to its 1987 closure and sell-off A/S Melbu Fiskeindustri's industrial plant comprised: seven large modern filleting, storage and freezing sheds in the harbour, and stand out 
prominently in the fjord-scape $600 \mathrm{~m}$ across the inlet at the tip of a long curving spit the Neptun oil production sheds and eleven storage tanks (fig. 8). As the loss of the production equipment did not alter the outward appearance, special coherence and historicity of this industrial landscape the Neptun complex was, the following year, 1988, placed on the national registry of historic structures. While the premise of the Norsk Fiskeindustrimuseum competition (for which no detailed brief was determined) implied proposals for the assessment of the reusability of and transformation of the empty industrial sheds the Corneils proposed a wider perspective for the project including the relationship with the town and the need for a strategy for the preservation, access and enhancement of the site as a whole. They understood the site to be a continuum from town to wharf to cultural-educational interpretation centre to the embarkation point for the Neptun site, in other words the setting of industrialised fishing as a whole, including the empty industrial yards, dilapidated wharf structures, empty storage tanks, unused boat slips, cranes and tracks would provide an authentic setting for a new cultural institution exhibiting. They insist that the coherent appreciation of the origins, traditions and evolution of the artifacts of pre-industrial and industrial fishing from this and other herring fishing sites are best appreciated within the context of the present-day realities of Melbu.

The Corneils' three-part submission proposed: simple, robust and economical interventions to protect and enhance existing view corridors and routes the town and wharf (paving, decking, curbs, retaining walls, wharves, industrial fences and gates, tree planting, parking layouts), to draw the visitors' attention to the key elements of the larger site: the fjord and coast, town and harbour, filleting plant in the port, and oil plant on the spit. Drawing attention to extended axes into the fjord landscape they sought to establish orientational priorities to 'explain' site, and contributing to the overall up-grading strategy they proposed to add 'ordinary' buildings to draw attention to on the site's structure within the natural structure (and beauty) of the setting. 'Fixing' the approach to the wharf from the town, the Christian Fredricksenalle and the E10, involves developing a strong link along the historic shoreline by coordinating the distribution and orientation of site and town visitors and ferry parking lots, vehicle-pedestrian forecourts, walkways, recreating a yard of fish-drying racks, and 'ordinary' service buildings for and visitor functions. The Neptun complex, a particularly heroic cluster isolated in the fjord, of simple sheds left to accommodate a growing collection/exhibition program, a $360^{\circ}$ panoramic cinema in a reused tank exhibition halls and basic visitor amenities. The pivotal position in the town-industry cross-axis if it is defined by the north-south town land axis (Fredricksenalle) meeting the east-west sea axis (Neptun) is the wedge-shaped site on the old wharf next to the existing industrial saltfisklager shed.

Here the Corneils' interpretation centre (tolkningsenter fig. 7) form is built-up of specifically- and variously-shaped elements so as best to negotiate the level changes, the rocky foreshore, link to the proposed timber klippfisk open airdrying racks and provide sheltered outdoor spaces on this open promontory. Part shed and part wharf, the tolkningsenter opens, extends, and inserts itself into the boxy saltfisklager and gives wide views of the fjorde to the south through 
continuous strip fenestration. The final formal iteration of is as an elongated, fragmented and low-lying structure merging with the horizontal folded geometry of drying racks, fjord and Lofoten mountain ridges beyond. From the special vantage point under the wharf and shed form tolkningsenter's deep overhangs information regarding the orientation of the industrial within the settled and natural landscapes could be assimilated: from the pedestrian route from the town's historic shoreline, to the adjacent saltfisklager, the embarkation wharf for the Neptun site in the foreground, the Neptun complex and quay in the middle distance and the vast mountain-edged fjord all around.

\section{Mo-i-Rana}

In the exceptionally beautiful and mineral rich area of Rana, $100 \mathrm{~km}$ from the open sea, in the Saltfjellet region just south of the Arctic circle, land, mining and exportation has been known since Prehistory. Since the $19^{\text {th }}$ century extensive mineral exploitation here has seen the hamlet and wharf of Moholmen at the head of Ranfjorde developed (once connected into the national rail network its own hydroelectric generator and a deep-water terminal) into the largest industrial zone in Norway: AS Norsk Jernverk. Pig iron production, initiated in the mid 1950s, grew into a six electric smelting furnace infrastructure in the 1960s and diversified to include ore dressing, rolling and finishing as wire, reinforcing bars and naval structural elements. In the global steel industry crisis of the mid 1980s the production of new steel here became uneconomic; the industry was refocused on scrap reprocessing, low level iron, steel and ferro-alloy production and a variety of small workshop and service industries, as well as some specialized industries and research and development companies. While the mono-functional steel-town was the subject of a number of new plans, such as Pedersen's 1923 garden city plan, the massive specialised industrial landscape (and its hinterland of industrial waste and pollution) is in many ways the more remarkable, with of course the surrounding fjord-land, than town itself. The Corneils' responded to a commission for programming ideas and sketch designs for an iron ore and steelworks museum/centre [15] for Mo-i-Rana, with three approaches to the interpretation of the physical inter-relationship between the landscape, settlement, and extraction and steelworks infrastructure. The Corneils' jernindustrikultursenter site studies (fig. 9) explore the juxtaposition here of nature-industry: of dark forests, deep cold rivers, massive machine halls, tanks, bridges, hoppers and conveyors. Their drawings suggest that both 'conditions' are, in a different ways, sublime and both dwarfs the town. Disinclined to think in terms of the autonomous architectural gesture their notes reveal their thinking that the defunct steelworks and terminal are unmatchable as figurative elements in the landscape and so Mo as a whole, in its post-industrial state, or as much of it as feasibly possible, is the museum/ centre. Their figureground studies show that both Pedersen's 1923 garden city plan and the industrial complex on the higher plateau are utopian projects and that like the Parc de Buttes de Chaumont in Paris industry waster sites can indeed make an urban garden. The Corneils' alternative projects for the iron industry centre are focused on the industrial waterfront, the west edge of the industrial plateau, and 


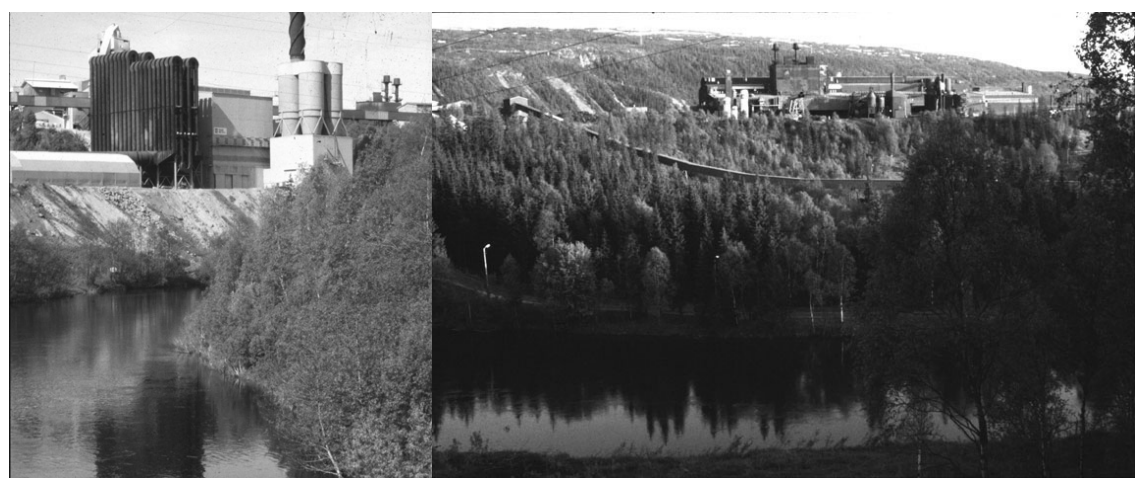

Figure 9: $\mathrm{E}$ and $\mathrm{C}$ Corneil. Pellet Figure 10: $\mathrm{E}$ and $\mathrm{C}$ Corneil. works and river valley, Mo-i-Rana, Norway. Photograph 1990. Steelworks and conveyor, Mo-i-Rana, Norway. Photograph 1990.

a town-to-industry itinerary and installation in the abandoned pellet works. The waterfront landfill district scheme, the Corneils first alternative, develops the zone between the city centre and industrial port, essentially cut-off by rail sidings and most likely to be developed by stand-alone interiorized atrium buildings, as an enclave of small to intermediate-scale building mediating between the town's small scale and the much larger lots and industrial yards further out along the E6. Conceived as a waterside neighbourhood with a hierarchy of arterial roads, boulevard parking tunnels, planted wind screens, pedestrian and bike paths and malls, public promenades in front of and behind short blocks of buildings with a fjord frontage of six brygge-like blocks and lot plans and a central canal and pool/rink plaza, the entire district opened to the water and punctuated by a pier on the Søndregate axis to replace the lost Moholmen Meyer pier. A crows-foot intersection mid-way up in the town gives a set of axial views down through the town's plan development in the 1930s and 1940 s to the water and diagonally to the deep-water port. The iron industry museum /centre could, if in an end block at the water, have a visual connection with the shipping terminal. The Corneils' plateau-edge alternative for the museum/ centre sitting high over the town is, like their 2000 NTNU Trondheim Competition project [16], reached up from an orientation centre, demonstration theatre, ramp/lift up at the escarpment base just off the proposed E6 route by car or across a pedestrian bridge they propose connecting with Kirkegata. The visitor would arrive on decks with panoramic views of the town and the fjord beyond part of a new structure attached to the existing steelworks administration building with level access to upper level observation galleries through the stilloperating areas of the industrial works. Their third, Kulterstien, alternative reconnects Moholmen via a 'back' route along the northern edge of the plateau through an older housing sector of Pedersen's plan (and by three house museums) and across the proposed E6 routing on a new pedestrian bridge next to a re-used steelworks shed (fig. 10), up a new ramping bridge though the midst of Mo's abandoned industrial landscape and into the silent, rusting pelletverks shed. 
Here the gigantic three-dimensional labyrinth of bins, mezzanines and stairs are the chief attraction; film though could be screened on the inner face of the unfenestrated walls from projection booths, seating and exhibit spaces inserted within the voids of infrastructure.

\section{References}

[1] Becher, B and H. Grain Elevators. MIT Press, 2006. cf the very different interpretation by Mahar-Keplinger, L. Grain Elevators, Princeton Architectural Press, 1993.

[2] Becher, B and H. Industrial Landscapes. MIT Press, 2002.

[3] Müller-Wulckow, W. Bauten der Arbeit und des Verkehrs aus deutscher Gegenwart. Königstein im Taunus and Leipzig, 1925; and (Neue, Erweiterte Ausgabe) 1929.

[4] Le Corbusier. Vers une architecture. (nouv. ed. revue et augmentée) Paris: Cres \& Cie, 1924.

[5] Linteau, P-A, 'Le développement du port de Montréal au début de siècle', Historical papers/Communications historiques, pp. 181-205, 1972.

[6] Banham, R. Concrete Atlantis. MIT Press, 1986.

[7] Price, C. 'Potteries Thinkbelt 1965' in Action and Inaction Cedric Price / Architectural Association Works 2, Architectural Association, p.18, 1984.

[8] Corneil C and Stinson J., 'Harbourfront Passage, Intergovernmental Waterfront Park', The Canadian Architect, 40-45. February 1974.

[9] Pinard, G. Montréal, son histoire, son architecture. Éditions du Méridien, vol. 6, 1995.

[10] See for example: Corneil E and C, 'Gare du Nord: a Canadian entry in the Arctic Center Competition, Rovaniemi, Finland' Section A 2/2, pp. 20-21, April/May 1984, and 'Nedre Elvehavn, utvikling av bydel, Trondheim', Norske Arkitektkonkurranser \#266 at Norske Arkitektkonkurranser Register 1953-2003 at http://www.arkitektur.no/page/Konkurranser_Arkiv/

[11] Corneil E e C, 'Dopo l'eruzione/Vestmannaeyjar, Iceland' Spazio e societa. 14, pp 6-24 and 99-105, Juno 1981; Byggekunst 6, pp.263-267, September 1980; The Canadian Architect pp.15-22, 1977; Arkitektnytt, September 1977; Arkitekten pp.225-233, June 1977.

[12] For example see: 'Norwegian Oil Museum in Stavanger', Byggekunst 82/1 pp.52-53, 2000; Polarmiljøsenteret og Polaria, Tromsø', Byggekunst 81/3 pp.27-31. 1999.

[13] Corneil, E. and C. 'Norske Arkitektkonkurranser \#314: Malmlageret i Narvik-idekonkurranse', Tillegg til Arkitektnytt nr. 19, Oslo, Norsk arkitekturforlag. pp 10-11, 1992.

[14] Hakon Mjelva 'Tanker ved Arsskiftet', Byggekunst 1, pp 2-8, 1963.

[15] Corneil, E. and C., 'Industrial history... A cross-disciplinary study for a museum of the steel industry in Rana', in Andersen H. A., Corneil C, Corneil E. and Espelin A., Norsk Industrikultur en tverrfaglig studie av et jernindustreimuseum Mo i Rana. Trondheim, pp. 133-137, 1992.

[16] Corneil, C., 'Extending the Plateau, Byggekunst vol 82/8, pp. 34-37, 2000. 